\title{
Nanoporous Silicon-Based Ammonia-Fed Fuel Cells
}

\author{
Tayyar D. Dzhafarov1, Sureyya Aydin Yuksel2, Mustafa Aydin² \\ ${ }^{1}$ Institute of Physics, Azerbaijan National Academy of Sciences, Baku, Azerbaijan \\ ${ }^{2}$ Department of Physics, Yildiz Technical University, Istanbul, Turkey \\ Email: caferov@physics.ab.az, surevya.aydin@gmail.com
}

Received 2 October 2014; revised 29 October 2014; accepted 16 November 2014

Copyright (C) 2014 by authors and Scientific Research Publishing Inc.

This work is licensed under the Creative Commons Attribution International License (CC BY).

http://creativecommons.org/licenses/by/4.0/

(c) (i) Open Access

\section{Abstract}

The objective of the paper is to report results on fabrication, structural, morphological and performance characteristics of novel $\mathrm{TiO}_{2} / \mathrm{PS} / \mathrm{Si}, \mathrm{Au} / \mathrm{TiO}_{2} / \mathrm{PS} / \mathrm{Si}$ and $\mathrm{Au} / \mathrm{PS} / \mathrm{Si}$ direct ammonia fuel cells (DAFC) using nanoporous silicon (PS) as proton conducting membrane (instead of traditional polymer Nafion membrane) and $\mathrm{TiO}_{2}, \mathrm{Au} / \mathrm{TiO}_{2}$ or $\mathrm{Au}$ as catalyst layer. Porous silicon layers have been prepared by electrochemical modification of silicon substrates. Films containing titanium dioxide are more efficient catalysts for hydrogen production from ammonia solution. The $\mathrm{Au} /$ $\mathrm{TiO}_{2} / \mathrm{PS} / \mathrm{Si}$ cell exhibited the open circuit voltage $0.87 \mathrm{~V}$ and performance of $1.6 \mathrm{~mW} / \mathrm{cm}^{2}$ with $50 \%$ ammonia solution as fuel at room temperature. Mechanisms of proton transport in nanoporous silicon membrane and generation of electricity in DAFC have been considered. Advantages of investigated direct ammonia fuel cells consist in simplicity of fabrication technology, which can be integrated into standard silicon micro fabrication processes and operation of cells at room temperature. The work demonstrates that the PS based fuel cells have potential for portable applications.

\section{Keywords}

Nanoporous Silicon Membrane, Fuel Cell, $\mathrm{Au} / \mathrm{TiO}_{2}$ Catalyst, Ammonia Electrolyte, Power Density

\section{Introduction}

Different types of hydrogen fuel cells have been intensively investigated as the effective sources of clean electric energy. Hydrogen is most preferred fuel but direct use of hydrogen in fuel cells meets a number of problems. Hydrogen does not exist naturally and its production, store and transportation meet difficulties. Moreover, hydrogen has a low energy density in comparing with the hydrogen-containing compositions (methanol, ethanol, 
ammonia etc.). Direct methanol fuel cell (DMFC) with proton conducting polymer membrane (Nafion) is considered as the promising type of fuel cell for small power-supply units. Platinum catalyst on the DMFC anode extracts hydrogen from liquid methanol. This process eliminates the need for fuel reformer for hydrogen production and allows using the methanol solution as a fuel. But DMFC has disadvantage due to moderate operating temperature (about $100^{\circ} \mathrm{C}$ ) and formation of CO pollutant gas. Moreover, the fabrication of DMFC with organic polymer membrane as proton conductors is not readily integrated with standard micro-fabrication technique that is widely used in production of most electronic devices.

Ammonia $\left(\mathrm{NH}_{3}\right)$ containing $17 \%$ hydrogen by weight is carbon-free, not explosive, not corrosive, nor highly flammable and it is being considered as a very promising source of hydrogen for fuel cells [1]. Energy density of ammonia $\left(13.6 \mathrm{GJ} / \mathrm{m}^{3}\right)$ is larger than that for hydrogen $\left(3.6 \mathrm{GJ} / \mathrm{m}^{3}\right)$. Ammonia can be produced commercially in large quantities. Ammonia has proven to be problematic for PEM fuel cells with Nafion membrane since both the conductivity of the membrane and the activity of the catalysts are adversely affected by trace ammonia in the fuel cells. Ammonia as hydrogen source was used for solid oxide fuel cells (SOFC). However, direct ammonia solid oxide fuel cell (DASOFC) operating at sufficiently high temperatures $\left(600^{\circ} \mathrm{C}-800^{\circ} \mathrm{C}\right)$ has received little attention until now [1]-[5]. It should be noted that the energetic expenses necessary for supporting of high operation temperatures result in a loss in efficiency for the SOFC system as a whole. Possibility of use of nanoporous gold electrode as effective anode catalyst for ammonia borane $\left(\mathrm{AB}-\mathrm{NH}_{3} \mathrm{BN}_{3}\right)$ oxidation reaction was studied in [5].

To overcome above disadvantages, we used the nanoporous silicon layer as proton-conducting membrane and $\mathrm{TiO}_{2}, \mathrm{Au} / \mathrm{TiO}_{2}$ or Au films as anode catalyst. Existence of pores with huge surface (up to $800 \mathrm{~m}^{2} / \mathrm{cm}^{3}$ ) determining large ion (proton) conductivity along the pores opens new perspectives for using porous silicon-based structures as hydrogen fuel cells. Porous silicon technology can be integrated into standard silicon micro fabrication processes. Previous studies devoted to fuel cells with the porous silicon membrane have been focused on direct methanol fuel cell [6] [7] sodium borohydride and hydrogen sulphide cells [8] [9]. To best of our knowledge, data on direct ammonia fuel cell with porous silicon electrolyte lack in literature.

This pioneer paper reports on fabrication details, structural and morphological properties of porous silicon and room temperature performance characteristics of new type direct ammonia fuel cell using proton conducting porous silicon membrane and $\mathrm{TiO}_{2}, \mathrm{Au} / \mathrm{TiO}_{2}$ or $\mathrm{Au}$ as catalyst.

\section{Experimental}

Porous silicon layers with thickness of 10 - $40 \mu \mathrm{m}$ and average porosity from $50 \%$ to $70 \%$ were prepared on ntype monocrystalline (111) Si substrates with resistivity of $1 \times 10^{-2} \Omega \cdot \mathrm{cm}$ by anodic etching in hydrofluoricethanol solution under the white light illumination [9]. For some measurements the PS films were then detached from Si substrate by electro-polishing. The free-standing PS films were characterized by porosity and thickness measurements. The average porosity, i.e. the void fraction in the porous layer was measured by gravimetry technique. Morphological characterizations of the porous silicon surface were performed by scanning electron microscopy (SEM; JSM-5410LV). The crystalline structure of porous silicon layers was studied by X-ray diffraction (XRD) measurements (Pananalitical Diffractometer, Philips, $\mathrm{CuK}_{\alpha 1}, \lambda=0.15406 \mathrm{~nm}$ ).

The $\mathrm{TiO}_{2} / \mathrm{PS} / \mathrm{Si}$ cells have been obtained by deposition of thin titanium dioxide film (about of $150 \mathrm{~nm}$ ) on PS/Si by using Titanium isopropoxide (TTIP)-Ethanol solution and spin coating technique. These structures have been treated at $450^{\circ} \mathrm{C}$ for $30 \mathrm{~min}$ in air ambient. The $\mathrm{Au} / \mathrm{PS} / \mathrm{Si}$ and $\mathrm{Au} / \mathrm{TiO}_{2} / \mathrm{PS} / \mathrm{Si}$ structures were fabricated by evaporation of a thin Au film onto the $\mathrm{PS} / \mathrm{Si}$ and $\mathrm{TiO}_{2} / \mathrm{PS} / \mathrm{Si}$ surface respectively at room temperature by using the electron-beam technique in vacuum of $1.3 \times 10^{-3} \mathrm{~Pa}$. The thickness of the deposited Au film was of $150 \mathrm{~nm}$ as obtained by the measurements during evaporation with the aid of a deposition controller (Inficon, Leybold). Electrical measurements of fuel cell characteristics were carried out using ammonia solution $\left(\mathrm{NH}_{3}: \mathrm{H}_{2} \mathrm{O}\right)$ of different concentrations.

The current-voltage characteristics, open-circuit voltage $\left(\mathrm{V}_{\text {oc }}\right)$ and short-circuit current density $(\mathrm{J})$ of the $\mathrm{TiO}_{2} / \mathrm{PS} / \mathrm{Si}, \mathrm{Au} / \mathrm{TiO}_{2} / \mathrm{PS} / \mathrm{Si}$ and $\mathrm{Au} / \mathrm{PS} / \mathrm{Si}$ cells were measured at room ambient (300 K, 40\% RH) as well as in ammonia solution in measuring cell $(300 \mathrm{~K})$. The ammonia-stimulated generation of the open-circuit voltage and short-circuit current between the contacts to $\mathrm{Au}$ or $\mathrm{TiO}_{2}$ film and $\mathrm{Si}$ substrate was measured directly by digital multi-meter (Thurlby-1503). The relative humidity of air was measured with hygro-thermometer (Extech44470). The photosensitive properties of the investigated cell structures were analyzed by measuring current-voltage characteristics in the dark and in daylight. All the cells exhibited weak photosensitivity and there- 
fore ammonia-stimulated measurements of current-voltage characteristics were performed under daylight conditions.

\section{Results and Discussion}

Figure 1 illustrates the SEM image of the PS, $\mathrm{Au} / \mathrm{PS}$ and $\mathrm{TiO}_{2} / \mathrm{PS}$ surfaces. Here the bright islands and relatively dark regions are the tops of silicon walls and intervals containing no of PS, respectively (Figure 1(a)). The larger dimensions of the bright islands on Au/PS surface than on the PS surface may be caused by $2-3$ neighboring islands covered by unbroken gold film (Figure 1(b)). SEM image of $\mathrm{TiO}_{2} / \mathrm{PS}$ surface is just like to PS surface image (Figure 1(c)). Figure 2 shows the X-ray diffraction patterns of monocrystalline Si substrate and porous silicon layer of $64 \%$ porosity. It is seen that the crystalline structure of porous silicon layer is similar to that of nearly perfect monocrystalline Si. Nature of peaks about at $39^{\circ}$ and $65^{\circ}$ in silicon can be tentatively attributed to SiC inclusions [10]. Lattice parameter of the porous silicon layer $(0.5528 \mathrm{~nm})$ was slightly bigger than that of silicon substrate $(0.5456 \mathrm{~nm})$. It can be caused by the lattice deformation of porous silicon.

Figure 3 shows the room temperature current density-voltage characteristics of four different types of struc-

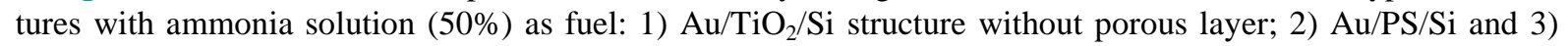
$\mathrm{TiO}_{2} / \mathrm{PS} / \mathrm{Si}$ cells with porous silicon layer and with single catalyst (Au or $\mathrm{TiO}_{2}$ respectively) and 4) $\mathrm{Au} / \mathrm{TiO}_{2} /$ PS/Si cell with double catalyst layers. It can be seen clearly from Figure 3 the short circuit current density for (3) $\mathrm{TiO}_{2} / \mathrm{PS} / \mathrm{Si}$ and (4) $\mathrm{Au} / \mathrm{TiO}_{2} / \mathrm{PS} / \mathrm{Si}$ cells is almost equal. The open circuit voltage for these cells ( 0.67 and $0.87 \mathrm{~V}$, respectively) is well over than that for $\mathrm{Au} / \mathrm{PS} / \mathrm{Si}$ cell $(0.35 \mathrm{~V})$. The $\mathrm{Au} / \mathrm{TiO}_{2} / \mathrm{Si}$ structure without porous silicon layer (curve 1) is very weakly sensitive to ammonia fuel. Thus the catalytic layer containing $\mathrm{TiO}_{2}$ plays main role in determining of electrical parameters of cells. Below will be presented mainly results of investigation of electrical characteristics of $\mathrm{TiO}_{2} / \mathrm{PS} / \mathrm{Si}$ cells with single catalyst layer taking into account theirs nearness to characteristics of $\mathrm{Au} / \mathrm{TiO}_{2} / \mathrm{PS} / \mathrm{Si}$ cells with double catalyst layers and simplicity of technology fabrication of cell with single catalyst $\mathrm{TiO}_{2}$ film.

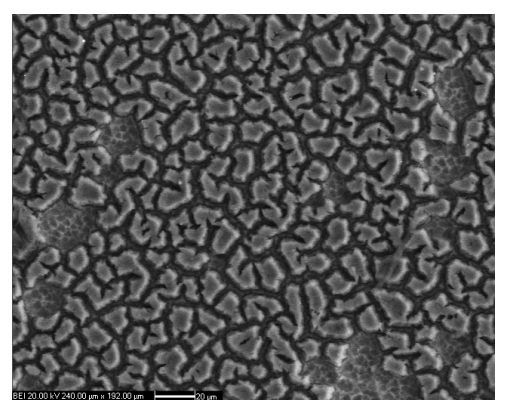

(a)

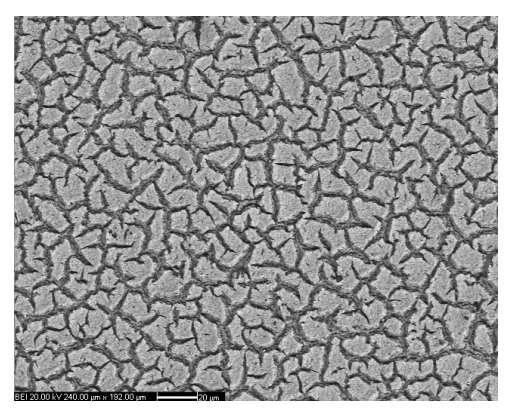

(b)

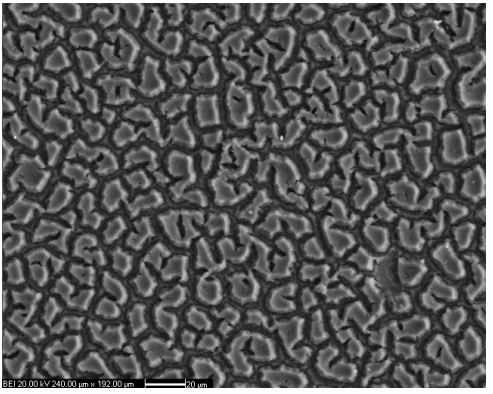

(c)

Figure 1. SEM micrographs of (a) PS; (b) $\mathrm{Au} / \mathrm{PS}$ and (c) $\mathrm{TiO}_{2} / \mathrm{PS}$ surfaces.

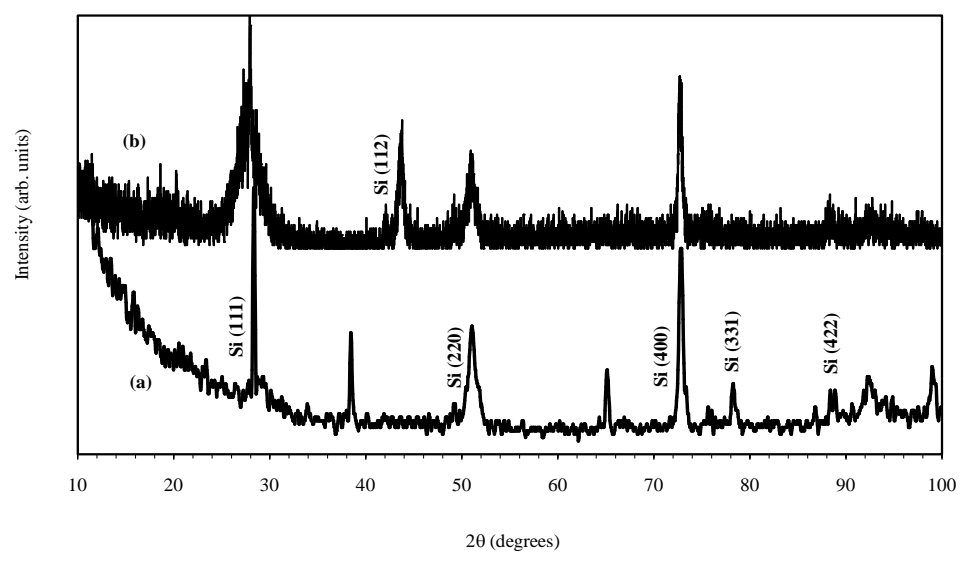

Figure 2. XRD patterns of (a) silicon substrate and (b) porous silicon layer. 


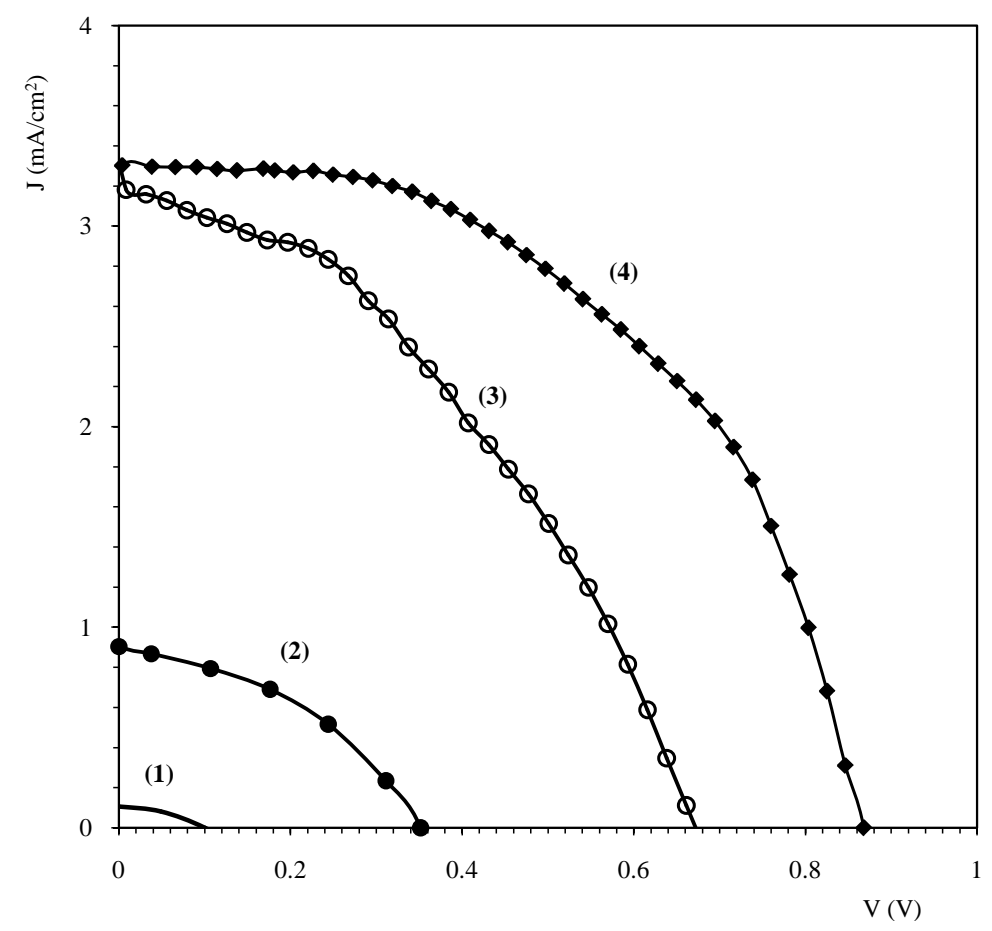

Figure 3. Current density-voltage characteristics of (1) $\mathrm{Au} / \mathrm{TiO}_{2} / \mathrm{Si}$, (2) $\mathrm{Au} /$ $\mathrm{PS} / \mathrm{Si}$, (3) $\mathrm{TiO}_{2} / \mathrm{PS} / \mathrm{Si}$ and (4) $\mathrm{Au} / \mathrm{TiO}_{2} / \mathrm{PS} / \mathrm{Si}$ cells with $50 \%$ ammonia solution as fuel $(300 \mathrm{~K})$.

The current density-voltage characteristics of $\mathrm{TiO}_{2} / \mathrm{PS} / \mathrm{Si}$ cell with ammonia for different concentrations at room temperature are presented in Figure 4 . It is seen that increase of ammonia concentration in the range $0 \%$ $50 \%$ is accompanied by increase of both the open circuit voltage and short circuit current density. Moreover, $\mathrm{TiO}_{2} / \mathrm{PS} / \mathrm{Si}$ cells produced the electricity $\left(\mathrm{V}_{\mathrm{oc}}=0.63 \mathrm{~V}, \mathrm{~J}=0.8 \mathrm{~mA} / \mathrm{cm}^{2}\right)$ with clear water. It should be noted that $\mathrm{Au} / \mathrm{TiO}_{2} / \mathrm{PS} / \mathrm{Si}$ and $\mathrm{Au} / \mathrm{PS} / \mathrm{Si}$ cells also showed characteristics of direct water fuel cell.

Figure 5 shows the performance of the $\mathrm{Au} / \mathrm{TiO}_{2} / \mathrm{PS} / \mathrm{Si}$ and $\mathrm{TiO}_{2} / \mathrm{PS} / \mathrm{Si}$ cells operating with $50 \%$ ammonia solution fuel and the $\mathrm{Au} / \mathrm{TiO}_{2} / \mathrm{PS} / \mathrm{Si}$ cell with water fuel. The maximum power density of the $\mathrm{Au} / \mathrm{TiO}_{2} / \mathrm{PS} / \mathrm{Si}$ and $\mathrm{TiO}_{2} / \mathrm{PS} / \mathrm{Si}$ cells operating at room temperature are $1.6 \mathrm{~mW} / \mathrm{cm}^{2}$ and $1.2 \mathrm{~mW} / \mathrm{cm}^{2}$ respectively. The lower performance of $0.25 \mathrm{~mW} / \mathrm{cm}^{2}$ was obtained for $\mathrm{Au} / \mathrm{TiO}_{2} / \mathrm{PS} / \mathrm{Si}$ cell with water fuel (Figure 5, curve (3)).

Thus the following experimental results were obtained on investigating the electrical characteristics of porous silicon based fuel cells operating at room temperature with ammonia solution as fuel.

a) $\mathrm{The} \mathrm{TiO}_{2} / \mathrm{PS} / \mathrm{Si}, \mathrm{Au} / \mathrm{TiO}_{2} / \mathrm{PS} / \mathrm{Si}$ and $\mathrm{Au} / \mathrm{PS} / \mathrm{Si}$ cells showed direct ammonia fuel cell properties at room temperature.

b) The open circuit voltage and short-circuit current density of cells increase with increase of ammonia concentration in the range $0 \%-50 \%$.

c) Titanium dioxide containing catalysts play the main role in determining of electrical parameters of cells. The electrical parameters of $\mathrm{Au} / \mathrm{TiO}_{2} / \mathrm{PS} / \mathrm{Si}$ and $\mathrm{TiO}_{2} / \mathrm{PS} / \mathrm{Si}$ cells with ammonia solution as fuel $\left(\mathrm{P}=1.6 \mathrm{~mW} / \mathrm{cm}^{2}\right.$, $\mathrm{V}_{\text {oc }}=0.87 \mathrm{~V}, \mathrm{~J}=3.3 \mathrm{~mA} / \mathrm{cm}^{2}$ and $\mathrm{P}=1.2 \mathrm{~mW} / \mathrm{cm}^{2}, \mathrm{~V}_{\text {oc }}=0.67 \mathrm{~V}, \mathrm{~J}=3.2 \mathrm{~mA} / \mathrm{cm}^{2}$ respectively, for $50 \% \mathrm{NH}_{3}$ fuel) are higher than those for Au/PS/Si cells with only Au catalyst $\left(\mathrm{V}_{\text {oc }}=0.35 \mathrm{~V}, \mathrm{~J}=0.9 \mathrm{~mA} / \mathrm{cm}^{2}\right)$.

d) The investigated cells also showed properties of direct water fuel cell at room temperature. $\mathrm{The} \mathrm{Au} / \mathrm{TiO}_{2} /$ $\mathrm{PS} /$ Si cell generated the electricity $\left(\mathrm{P}=0.25 \mathrm{~mW} / \mathrm{cm}^{2}\right)$ with water as fuel.

We suggest that the mechanism of the generation of the electricity in investigated cells is similar to proposed early mechanism generation for $\mathrm{Au} / \mathrm{PS} / \mathrm{Si}$ cell exposed directly hydrogen or hydrogen-containing composition as fuel [9]. Herewith $\mathrm{TiO}_{2}, \mathrm{Au} / \mathrm{TiO}_{2}$ or Au films play the role of the catalytic anode for $\mathrm{TiO}_{2} / \mathrm{PS} / \mathrm{Si}, \mathrm{Au} / \mathrm{TiO}_{2} / \mathrm{PS} / \mathrm{Si}$ or $\mathrm{Au} / \mathrm{PS} / \mathrm{Si}$ cell respectively. The porous silicon layer acts as proton-conducting membrane and the PS/Si interface which is very imperfect and stressed plays the role of the cathode. Data of Figure 3 and Figure 5 related with best electrical parameters of $\mathrm{Au} / \mathrm{TiO}_{2} / \mathrm{PS} / \mathrm{Si}$ cell in comparing with those for $\mathrm{TiO}_{2} / \mathrm{PS} / \mathrm{Si}$ and $\mathrm{Au} / \mathrm{PS} / \mathrm{Si}$ cells 


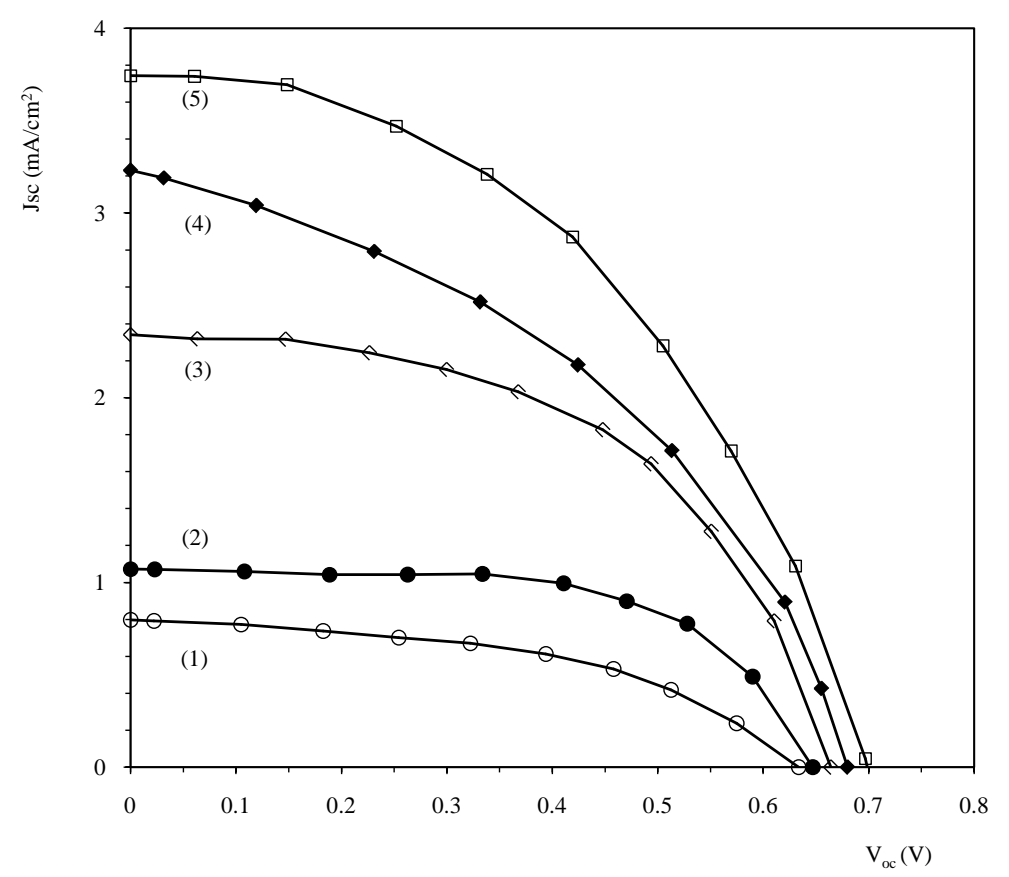

Figure 4. Current density-voltage characteristics of $\mathrm{TiO}_{2} / \mathrm{PS} / \mathrm{Si}$ cell with (1) $\mathrm{H}_{2} \mathrm{O}$, ammonia solutions of (2) $1 \%$, (3) $10 \%$, (4) $20 \%$, (5) $50 \%$ (300 K).

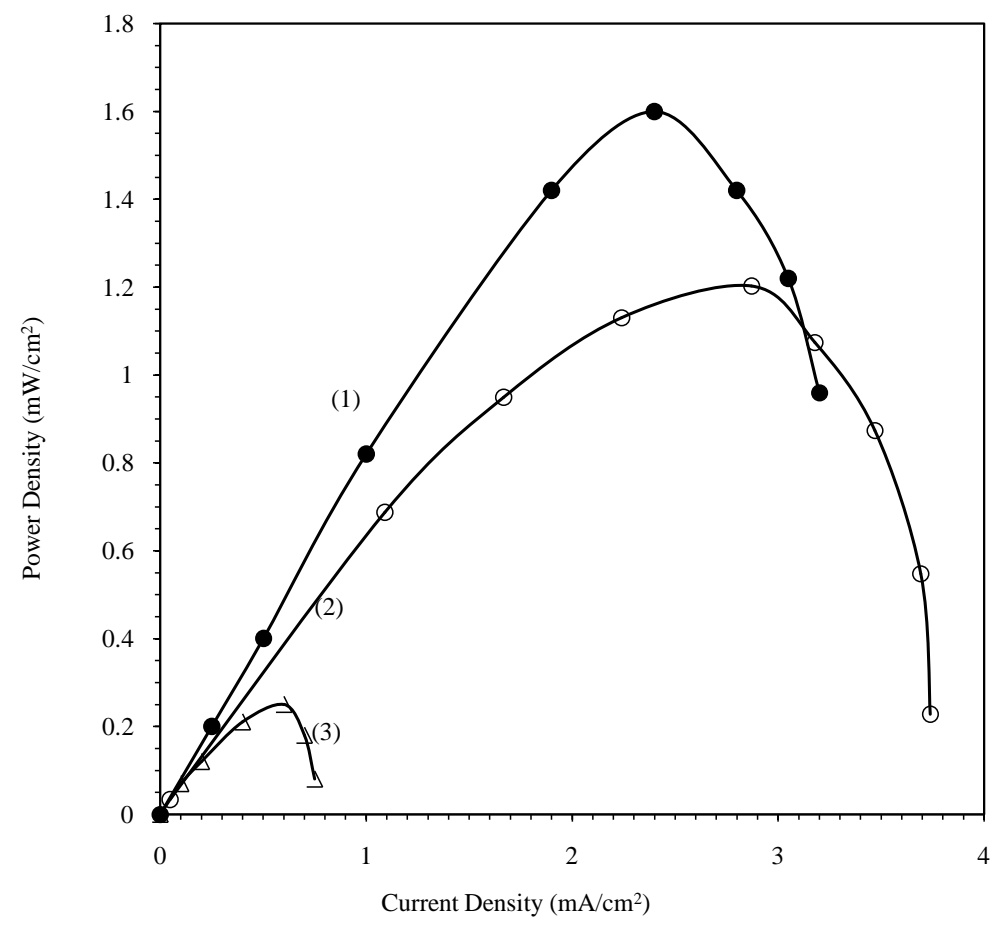

Figure 5. Power density versus current density curves: (1) $\mathrm{Au} / \mathrm{TiO}_{2} / \mathrm{PS} / \mathrm{Si}$ and (2) $\mathrm{TiO}_{2} / \mathrm{PS} / \mathrm{Si}$ cells with $50 \%$ ammonia solution fuel, (3) $\mathrm{Au} / \mathrm{TiO}_{2} / \mathrm{PS} / \mathrm{Si}$ cell with water fuel $(300 \mathrm{~K})$.

one can to comment as result of more efficient hydrogen production from ammonia solution for double $\mathrm{Au}_{\mathrm{TiO}}$ catalyst film. Electrochemical reactions proceeding in direct ammonia fuel cell with porous silicon proton-conducting can be expressed as [11]: 


$$
\text { At the anode: } 2 \mathrm{NH}_{3} \rightarrow 3 \mathrm{H}_{2}+\mathrm{N}_{2}
$$

$$
3 \mathrm{H}_{2} \rightarrow 6 \mathrm{H}^{+}+6 \mathrm{e}^{-}
$$

At the cathode : $3 / 2 \mathrm{O}_{2}+6 \mathrm{e}^{-} \rightarrow 3 \mathrm{O}^{2-}$

$$
6 \mathrm{H}^{+}+3 \mathrm{O}^{2-} \rightarrow 3 \mathrm{H}_{2} \mathrm{O}
$$

The overall reaction : $2 \mathrm{NH}_{3}+3 / 2 \mathrm{O}_{2} \rightarrow \mathrm{N}_{2}+3 \mathrm{H}_{2} \mathrm{O}$

Electrons and protons formed in the $\mathrm{Au} / \mathrm{TiO}_{2}, \mathrm{TiO}_{2}$ or Au catalyst film pass through the external circuit and PS membrane, respectively, and reach the cathode (PS/Si interface). Here the hydrogen and electron is recombined producing hydrogen molecule which reacts with oxygen to form water molecules.

It is evident that the open circuit voltage produced in $\mathrm{Au} / \mathrm{TiO}_{2} / \mathrm{PS} / \mathrm{Si}$ direct ammonia fuel cell was sufficiently large whereas values of the short circuit current density and thereby the cell performance were lower than those presented for direct ammonia SOFC operating at higher temperatures [2]-[4]. This may be caused (besides low temperature operation of presented porous silicon based cells) also by the low proton-conductivity of porous silicon membrane. It is known that structure of porous silicon is like a sponge or columnar and pore surfaces are covered by silicon hydrides ( $\mathrm{Si}-\mathrm{H})$ and silicon oxides (Si-O). We suppose that the proton conductivity in PS layer is mainly realized via broken bonds of Si-H. Our estimation value of the proton conductivity of porous silicon layer with use the data on diffusion coefficient of hydrogen in PS [12] gave about $12-15 \mathrm{mS} / \mathrm{cm}$ which is lower than proton conductivity of Nafion membrane (about $40 \mathrm{mS} / \mathrm{cm}$ ) which is used in DMFC [13]. The increase of proton conductivity porous silicon membranes and thereby improvement of performance of DAFC can be actualized by using of PS filled with acidic solutions ( $\mathrm{HCl}, \mathrm{H}_{2} \mathrm{SO}_{4}$ etc.) to partially oxidize the pore surfaces. We are presently searching for more efficient oxidization of pores surfaces.

\section{Conclusion}

Thus, preparation and characterization of novel direct ammonia fuel cell using porous silicon proton conduction membrane, $\mathrm{TiO}_{2}$ or $\mathrm{Au} / \mathrm{TiO}_{2}$ layer as catalyst and ammonia solution as fuel was demonstrated in this report. The open circuit voltage of $0.87 \mathrm{~V}$ and power density of $1.6 \mathrm{~mW} / \mathrm{cm}^{2}$ were achieved for $\mathrm{Au} / \mathrm{TiO}_{2} / \mathrm{PS} / \mathrm{Si}$ fuel cell operating at room temperature. Moreover, the investigated type of fuel cells generated the electricity also with water as fuel at room temperature. Advantages of investigated direct ammonia fuel cells consist in simplicity of fabrication technology, which can be integrated into standard silicon micro fabrication processes and operation of cells at room temperature. Further improvement of performance of porous silicon based DAFC are still needed for portable applications.

\section{Acknowledgements}

The study was supported by the Research Found (2012-01-01-YL04) of Yildiz Technical University.

\section{References}

[1] Cheddia, D. (2012) Ammonia as a Hydrogen Source for Fuel Cells. In: Minic, D., Ed., Hydrogen Energy—Challenges and Perspectives, Intech, Rijeka, 333-362. http://dx.doi.org/10.5772/47759

[2] Limin, Z., You, C., Weishen, Y. and Liwu, L. (2007) A Direct Ammonia Tubular Solid Oxide Fuel Cell. Chinese Journal of Catalysis, 28, 749-751. http://dx.doi.org/10.1016/S1872-2067(07)60062-X

[3] Limin, Z. and Weishen, Y. (2008) Direct Ammonia Solid Oxide Fuel Cell Based on Thin Proton-Conducting Electrolyte. Power Sources, 179, 92-95. http://dx.doi.org/10.1016/j.jpowsour.2007.12.061

[4] Simons, E.L., Cairns, E.J. and Surd, D. (1969) The Performance of Direct Ammonia Fuel Cells. Journal of the Electrochemical Society, 116, 556-561. http://dx.doi.org/10.1149/1.2411961

[5] Nagle, L.C. and Rohan, J.F. (2011) Nanoporous Gold Catalyst for Direct Ammonia Borane Fuel Cells. Journal of the Electrochemical Society, 158, B772-B776. http://dx.doi.org/10.1149/1.3583637

[6] Dzhafarov, T.D. and Yuksel, S.A. (2011) Nano-Porous Silicon-Based Mini Hydrogen Fuel Cells. In: Manzanera, M., Ed., Alternative Fuel, Intech, Rijeka, 309-334. http://dx.doi.org/10.5772/25272

[7] Li, X. and Faghri, A. (2013) Review and Advances of Direct Methanol Fuel Cells (DMFCs) Part I: Design, Fabrication, 
and Testing with High Concentration Methanol Solutions. Power Sources, 226, 223-240. http://dx.doi.org/10.1016/j.jpowsour.2012.10.061

[8] Dzhafarov, T.D., Oruc Lus, C., Aydin Yuksel, S., Yesilkaya, S. and Caliskan, M. (2010) Au/Porous Silicon-Based Sodium Borohydride Fuel Cells. International Journal of Energy Research, 34, 1386-1392. http://dx.doi.org/10.1002/er.1680

[9] Dzhafarov, T.D. and Aydin Yuksel, S. (2011) Porous Silicon-Based Direct Hydrogen Sulphide Fuel Cell. Journal of Nanoscience and Nanotechnology, 11, 9012-9015.

[10] Chen, H., Liu, J. and Huang, W. (2006) Corrosion Behavior of Silicon Nitride Bonding Silicon Carbide in Molten Magnesium and AZ91 Magnesium Alloy. Materials Science and Engineering: A, 415, 291-296. http://dx.doi.org/10.1016/j.msea.2005.09.106

[11] Zamfiresku, C. and Dincer, I. (2008) Using Ammonia as a Sustainable Fuel. Journal of Power Sources, 185, 459-465. http://dx.doi.org/10.1016/j.jpowsour.2008.02.097

[12] Dzhafarov, T.D. and Can, B. (2000) The Diffusion Redistribution of Hydrogen and Oxygen in Porous Silicon Films. Journal of Materials Science Letters, 19, 287-290. http://dx.doi.org/10.1023/A:1006746226563

[13] Chu, K., Shanon, M.A. and Masel, R.I. (2007) Porous Silicon Fuel Cells for Micro Power Generation. Journal of Micromechanics and Microengineering, 17, S243-S248. http://dx.doi.org/10.1088/0960-1317/17/9/S06 
Scientific Research Publishing (SCIRP) is one of the largest Open Access journal publishers. It is currently publishing more than 200 open access, online, peer-reviewed journals covering a wide range of academic disciplines. SCIRP serves the worldwide academic communities and contributes to the progress and application of science with its publication.

Other selected journals from SCIRP are listed as below. Submit your manuscript to us via either submit@scirp.org or Online Submission Portal.
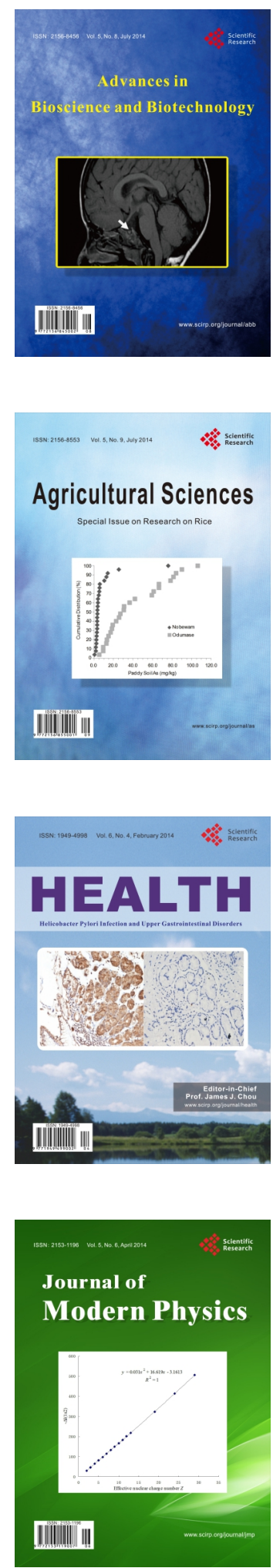
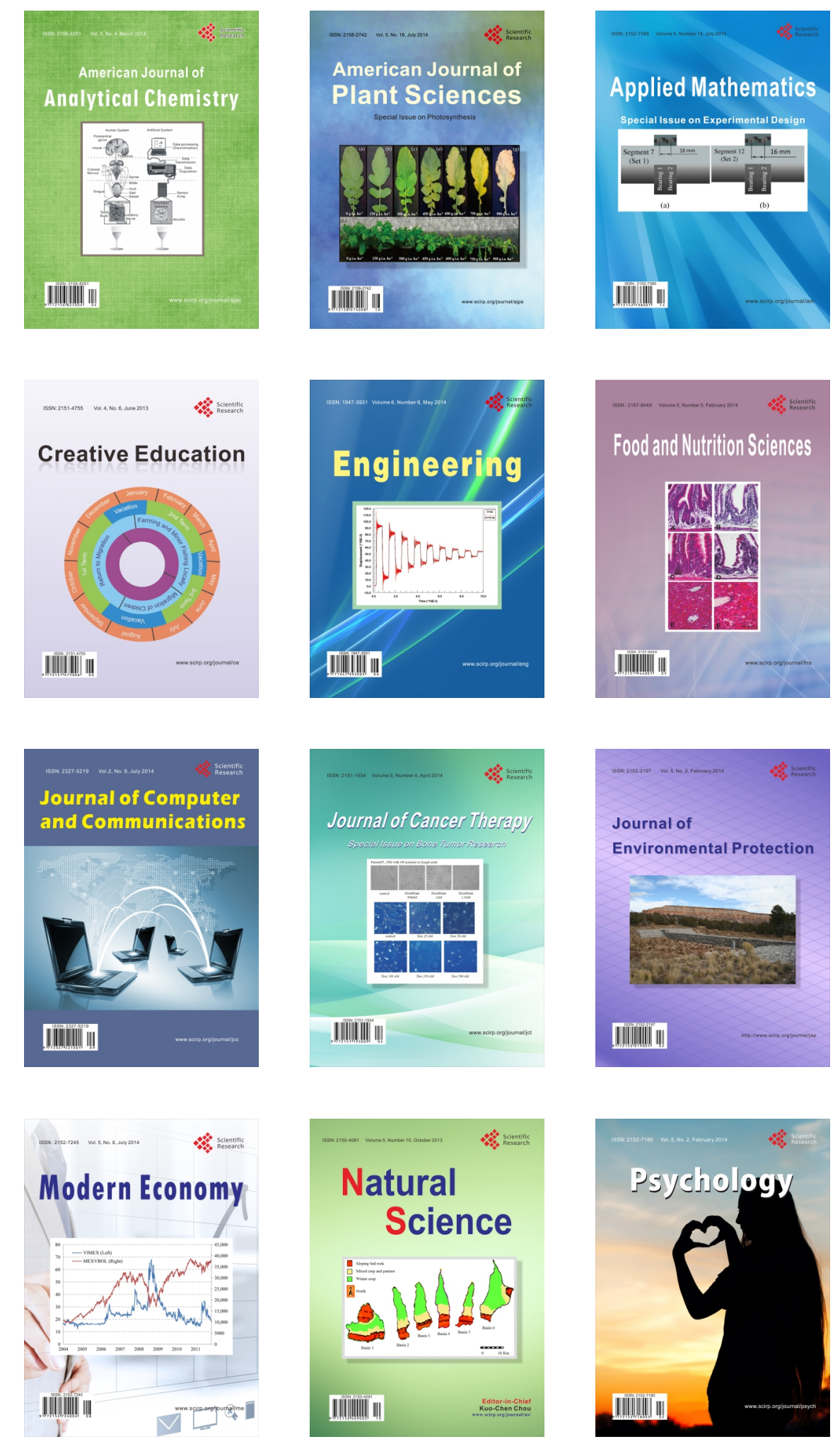